\title{
PENGEMBANGAN EKOWISATA BERBASIS MASYARAKAT
}

\author{
Rudy Pramono ${ }^{1}$, D. M. Lemy ${ }^{2}$, L. Soemarni ${ }^{3}$ A. Pramezwary ${ }^{4}$ Y Kristiana ${ }^{5}$ \\ ${ }^{1245}$ Universitas Pelita Harapan, Tangerang \\ ${ }^{3}$ Institut Pradita, Tangerang \\ rudy.pramono@uph.edu
}

\begin{abstract}
Abstrak
Ekowisata berbasis masyarakat mampu memberikan kesempatan kerja bagi masyarakat setempat dan meningkatkan pendapatan. Sumber penghasilan ekowisata adalah dari jasa-jasa wisata untuk wisatawan seperti pemandu wisata, transportasi, penyewaan tempat tinggal , menjual kerajinan, dan sebagainya. Kegiatan ini ditujukan untuk mewujudkan Kelurahan Keranggan sebagai kelurahan ekowisata berbasis masyarakat dengan dukungan mitra Pemerintah Kelurahan Keranggan dan Koperasi Cipta Boga. Kesiapan masyarakat dan pengelola lokal dalam kegiatan ekowisata saat ini masih sangat kurang. Untuk mewujudkan tujuan ini selain mempersiapkan fasilitas perlu mempersiapkan masyarakat dan pengelola lokal yang mampu menjalankan kegiatan ekowisata berbasis masyarakat secara berkelanjutan. Metode yang akan dipakai dalam kegiatan ini dimulai dengan awal pelaksanaan ini adalah sosialisasi program ekowisata berbasis masyarakat, tahap kedua adalah pembentukan tim usaha yang akan dikoordinir oleh mitra Pemerintah Kelurahan dan KSU Cipta Boga, tahap ketiga mengadakan penyuluhan maupun pelatihan untuk meningkatkan kompetensi sumber daya manusia dalam pengelolaan atraksi wisata, tahap keempat peresmian ekowisata, tahap kelima kerja sama dan promosi, tahap terakhir merupakan tahap pendampingan dan evaluasi keberlanjutan. Tahap ekowisata berbasis masyarakat berkelanjutan ini merupakan hasil akhir dari serangkaian program yakni terbentuknya ekowisata berbasis masyarakat yang sinergis dan menarik di kawasan Keranggan secara berkelanjutan.
\end{abstract}

Kata Kunci : ekowisata, berbasis masyarakat, jasa wisata, Keranggan, berkelanjutan

\section{PENDAHULUAN}

Kelurahan Keranggan Kec. Setu Kota Tangerang Selatan merupakan kelurahan yang masih didominasi warga pribumi dan memiliki banyak pelaku industri rumah tangga. Lokasi Keranggan terletak di pinggiran sungai Cisadane dengan luas wilayah sekitar 50 hektar. Sebagian besar warga Keranggan sebagai pengusaha industri rumah tangga, sehingga Pemerintah Kota Tangerang Selatan akan menjadikan Keranggan sebagai kampung ekowisata atau kampung pariwisata industri. Kelurahan
Keranggan bakal dikembangkan menjadi pusat industri rumahan Kota Tangerang Selatan. Menurut rencana di Kelurahan Keranggan akan menjadi tempat yang menyediakan berbagai produk industri rumahan seperti peyek, emping, krupuk, dodol, kripik, kacang sanggrai, kue basah, lopis ataupun singkong. Total jumlah usaha menengah kecil dan mikro yang rutin menjalankan aktivitas usahanya sekitar 200, dan sebagian besar masih bersifat tradisional, mulai dari pengolahan bahan mentah, proses memasak, mengemas sampai melakukan pemasaran masih dilakukan secara manual.

Ekonomi, Sosial, dan Budaya

1471 
Para pelaku usaha kecil di Keranggan pada umumnya sudah tergabung dalam Koperasi Cipta Boga, yang berperan dalam membantu pengembangan usaha mereka. Misi Koperasi Cipta Boga antara lain: 1) membangun kesejahteraan anggota dan masyarakat, 2) memberikan layanan prima bagi anggota, 3) menjalin kemitraan yang profesional dan saling menguntungkan, 4) menciptakan sumber daya manusia yang tangguh dan mandiri. Aktivitas yang dilakukan Koperasi Cipta Boga antara lain: konsultasi usaha, memfasilitasi perencanaan bisnis, memfasilitasi permodalan usaha, memfasilitasi manajemen usaha, memfasilitasi legalitas usaha, memfasilitasi analisis profil usaha, memfasilitasi pemasaran, restrukturasi usaha, pendampingan usaha, branding dan pelatihan. Koperasi ini dipimpin oleh Bapak Alwani, yang mempunyai fokus pada enam unit usaha yaitu: simpan pinjam, produksi, dagang dan jasa, pariwisata, tani dan tanaman dan percetakan.

Letak kelurahan Keranggan yang berada di sepanjang sisi Sungai Cisadane dan berada tidak jauh dari pusat perkembangan perdagangan di Bumi Serpong Damai dan Kota Tangerang Selatan dan potensi yang ada di masyarakat mempunyai potensi untuk dikembangkan menjadi kawasan ekowisata. Dengan rencana pengembangan ekowisata Cisadane di Kelurahan Keranggan ini mempunyai potensi untuk mengerakkan ekonomi masyarakat, kelestarian lingkungan dan peningkatan kesejahteraan masyarakat.

Pola ekowisata berbasis masyarakat adalah pola pengembangan ekowisata yang mendukung dan memungkinkan keterlibatan penuh oleh masyarakat setempat dalam perencanaan, pelaksanaan, dan pengelolaan usaha ekowisata dan segala keuntungan yang diperoleh. Ekowisata berbasis masyarakat merupakan usaha ekowisata yang menitikberatkan peran aktif komunitas. Hal tersebut didasarkan kepada kenyataan bahwa masyarakat memiliki pengetahuan tentang alam serta budaya yang menjadi potensi dan nilai jual sebagai daya tarik wisata, sehingga pelibatan masyarakat menjadi mutlak. Pola ekowisata berbasis masyarakat mengakui hak masyarakat lokal dalam mengelola kegiatan wisata di kawasan yang mereka miliki secara adat ataupun sebagai pengelola.

Ekowisata berbasis masyarakat dapat menciptakan kesempatan kerja bagi masyarakat setempat, dan mengurangi kemiskinan, dimana penghasilan ekowisata adalah dari jasa-jasa wisata untuk wisatawan seperti fee pemandu, biaya transportasi, penyewaan homestay, menjual kerajinan, dan sebagainya. Ekowisata membawa dampak positif terhadap pelestarian lingkungan dan budaya asli setempat yang pada akhirnya diharapkan akan mampu menumbuhkan jati diri dan rasa bangga antar penduduk setempat yang tumbuh akibat peningkatan kegiatan ekowisata.

Dengan adanya pola ekowisata berbasis masyarakat bukan berarti bahwa masyarakat akan menjalankan usaha ekowisata sendiri. Tataran implementasi ekowisata perlu dipandang sebagai bagian dari perencanaan pembangunan terpadu yang dilakukan di suatu daerah. Untuk itu, pelibatan para pihak terkait mulai dari level komunitas, masyarakat, pemerintah, dunia usaha dan organisasi non pemerintah diharapkan membangun suatu jaringan dan menjalankan suatu kemitraan yang baik sesuai peran dan keahlian masing-masing. Beberapa aspek kunci dalam ekowisata berbasis masyarakat adalah:

1. Masyarakat membentuk panitia atau lembaga untuk pengelolaan kegiatan ekowisata di daerahnya, dengan dukungan dari pemerintah dan organisasi masyarakat (nilai partisipasi masyarakat dan edukasi);

2. Prinsip local ownership (pengelolaan dan kepemilikan oleh masyarakat setempat) diterapkan sedapat mungkin terhadap sarana dan prasarana ekowisata, kawasan ekowisata, dan lain-lain (nilai partisipasi masyarakat);

$$
\text { Ekonomi, Sosial, dan Budaya }
$$

1472 
3. Homestay menjadi pilihan utama untuk sarana akomodasi di lokasi wisata (nilai ekonomi dan edukasi);

4. Pemandu adalah orang setempat (nilai partisipasi masyarakat);

5. Perintisan, pengelolaan dan pemeliharaan obyek wisata menjadi tanggungjawab masyarakat setempat, termasuk penentuan biaya untuk wisatawan (nilai ekonomi dan wisata).

Untuk dapat mewujudkan ekowisata berbasis masyarakat ini selain daya dukung fasilitas wisata, yang paling penting adalah kesiapan masyarakat dan pengelola lokal yang akan mengelola dan memelihara kegiatankegiatan wisata yang akan dilakukan. Kesiapan masyarakat dan pengola lokal dalam kegiatan ekowisata ini, masih sangat kurang.

Program yang ditawarkan melalui Program Kemitraan Masyarakat dalam rangka pengabdian kepada masyarakat dilakukan untuk memberikan pengetahuan dan keterampilan mitra dan masyarakat. Berdasarkan uraian di atas maka solusi yang ditawarkan adalah sebagai berikut:

1. Memberikan sosialisasi, penyuluhan dan pendampingan tentang pengelolaan ekowisata yang berbasis masyarakat. Penyuluhan ini bertujuan untuk meningkatkan pengetahuan masyarakat.

2. Memberikan sosialisasi dan pendampingan tentang manfaat kegiatan pariwisata yang bertujuan untuk meningkatkan kesadaran masyarakat tentang manfaat kegiatan pariwisata.

3. Memberikan pelatihan dan pendampingan tentang pengelolaan atraksi wisata yang bertujuan untuk meningkatkan pengetahuan masyarakat tentang kegiatan wisata.

4. Memberikan pelatihan dan pendampingan tentang penyusunan paket wisata yang bertujuan untuk meningkatkan pengetahuan masyarakat tentang penyusunan paket kegiatan wisata yang mampu memperpanjang lama tinggal wisatawan.

5. Memberikan pelatihan dan pendampingan tentang kualitas layanan yang bertujuan untuk meningkatkan layanan yang diberikan kepada wisatawan.

6. Memberikan pelatihan dan pendampingan tentang pembuatan brosur yang memuat informasi tentang atraksi, akomodasi dan aktivitas wisata yang terdapat di Kelurahan Keranggan.

\section{METODE}

Tahap awal pelaksanaan ini adalah sosialisasi program. Setelah tim menemukan potensi-potensi yang dapat dikembangkan seperti potensi alam, potensi ekonomi, sosial dan sumber daya manusia yang mendukung untuk mengembangkan program ekowisata berbasis masyarakat di kawasan Kelurahan Keranggan Kec. Setu Kota Tangerang Selatan. Sosialisasi ini akan dilaksanakan untuk menyampaikan program program yang akan dilaksanakan di kawasan tersebut dalam rangka kegiatan pengembangan ekowisata berbasis masyarakat.

Tahap kedua adalah pembentukan tim usaha yang akan dikoordinir oleh Pemerintah Kelurahan dan KSU Cipta Boga yang melibatkan pelaku usaha industri rumah tangga pemuda dan pemudi beserta tokoh masyarakat yang akan mempermudah dalam penggerakan masyarakat dalam program pengembangan ekowisata berbasis masyarakat ini. Pembentukan tim usaha ekowisata akan mengerucut ke dalam sistem koperasi jasa wisata yang anggota dan pengurusnya merupakan masyarakat kelurahan. Untuk menunjang atraksi ekowisata Keranggan lebih kompleks maka akan dibentuk kelompokkelompok kecil yang akan membidangi secara spesifik atraksi wisata seperti wisata alam dan petualangan, wisata budaya serta wisata edukasi.

Tahap ketiga setelah pembentukan tim usaha adalah mengadakan penyuluhan maupun pelatihan untuk meningkatkan kompetensi sumber daya manusia dalam pengelolaan atraksi

$$
\text { Ekonomi, Sosial, dan Budaya }
$$


wisata. Penyuluhan dan pelatihan akan dilaksanakan dalam berbagai bidang yakni bidang kepariwisataan dan pemandu, bidang kebudayaan dan kuliner, serta bidang edukasi dan pelestarian lingkungan. Pengadaan fasilitas penunjang pun akan direalisasikan seperti papan informasi, peralatan outbound, tempat parkir, dan papan peringatan.

Tahap keempat selanjutnya merupakan peresmian ekowisata Kelurahan Keranggan yang ditargetkan akan diresmikan oleh pejabat di Kota Tangerang Selatan, dan akan dilaunching dengan tema "Pesta Rakyat yang Berbudaya".

Tahap kelima selanjutnya merupakan tahap promosi yang mana tahap promosi ini akan berperan penting dalam pemasaran ekowisata Keranggan. Target sasaran kerja sama promosi yaitu stasiun radio, media cetak, lembaga pendidikan, biro perjalanan wisata dan media sosial. Melalui promosi diharapkan akan timbul kerja sama dari pihak lain untuk mengembangkan program ekowisata.

Tahap terahkir merupakan tahap pendampingan dan evaluasi. Program pendampingan sendiri berupa pendampingan langsung ke lapangan maupun pendampingan melalui perantara media. Pendampingan berupa pengelolaan ekowisata, pemasaran, dan pengembangan program bila diperlukan. Kemudian tahap evaluasi, tahap ini merupakan tahap dimana program akan dievaluasi secara menyeluruh untuk meningkatkan mutu program dalam pengembangan program selanjutnya.

Tahap ekowisata berbasis masyarakat berkelanjutan ini merupakan hasil akhir dari serangkaian program yakni terbentuknya ekowisata berbasis masyarakat yang sinergis dan menarik di kawasan Keranggan secara berkelanjutan.

\section{HASIL DAN PEMBAHASAN}

Sosialisasi dilaksanakan pada awal Agustus 2018 dan menghasilkan kesepakatan untuk menjalankan program pengembangan ekowisata berbasis masyarakat di kawasan Keranggan bekerja sama dengan Koperasi Cipta Boga . Sosialisasi ini tim pelaksana $\mathrm{PkM}$ diterima dengan baik dan antusias warga dan koperasi Cipta Boga yang positif. Dalam sosialisasi tim menyampaikan potensi-potensi yang ada di sekitar kawasan Keranggan, seperti potensi alam, potensi ekonomi lokal, potensi budaya, potensi edukasi pertanian tadisional, dan potensi kuliner yang akan dikembangkan untuk menunjang ekowisata Keranggan. Selain itu,ditemukan berbagai persoalan dicarikan solusi bersama pada saat pengabdian dilaksanakan.

Dua minggu berikutnya sampai minggu ketiga September setelah melaksanakan tahap sosialisasi tim bersama masyarakat membentuk kelompok pengelola usaha ekowisata yang nantinya akan menjadi penggerak ekowisata di Keranggan. Dalam pembentukan ini menemukan kesepakatan bekerjasama dengan karang taruna, dan masyarakat umum lainya yang terwadahi dalam koperasi Cipta Boga yang sudah ada sebelumnya. Dalam tahap ini tim berhasil membentuk berbagai kelompok yang akan menjadi penggerak atraksi ekowisata dan pemecahan masalah usaha kecil industri rumah tangga di Keranggan, yang akan menjadi tujuan wisata ekonomi di kawasan ekowisata Keranggan

Tahap berikutnya koordinasi tim pengelola usaha ekowisata mengenai akan diselenggarakannya pelatihan, penyuluhan sesuai dengan yang dibutuhkan masyarakat, antara laian :

a. Pelatihan dan pendampingan tentang pengelolaan atraksi wisata yang bertujuan untuk meningkatkan pengetahuan masyarakat tentang pengelolaan kegiatan wisata,

b. Pelatihan penyusunan paket wisata yang bertujuan untuk meningkatkan pengetahuan masyarakat tentang penyusunan paket wisata yang mampu memperpanjang lama tinggal wisatawan.

Ekonomi, Sosial, dan Budaya

1474 
c. Pelatihan kualitas layanan yang bertujuan untuk meningkatkan layanan yang diberikan kepada wisatawan serta

d. Pelatihan pembuatan brosur yang memuat informasi tentang atraksi, akomodasi dan aktivitas wisata yang terdapat di Kelurahan Keranggan

Kegiatan pelatihan telah diselenggarakan pada hari Rabu, 18 Oktober 2018 dengan diikuti tim inti pengelola usaha ekowisata Keranggan di Kampus Institut Pradita Tangerang.

Deskripsi jadwal kegiatan:

1. Tahap survey persiapan akan dilakukan pada bulan pertama. Persiapan ini bertujuan untuk mengidentifikasi kebutuhan pelatihan berdasarkan skala prioritas.

2. Koordinasi dengan kelompok masyarakat dan pemerintah kelurahan terkait:

a. Penyusunan modul pelatihan dilakukan pada bulan ketiga.

b. Pelaksanaan pelatihan akan dilakukan di bulan kedua hingga ketiga.

3. Proses pendampingan sudah mulai dilakukan di bulan keempat hingga bulan kelima.

4. Monitoring dan evaluasi dilakukan mulai bulan keempat hingga bulan kelima.

5. Puncak kegiatan akan diadakan Festival Keranggan untuk promosi dan launching paket wisata yang diadakan Bulan Desember 2018

6. Publikasi kegiatan akan dilaksanakan pada bulan Oktober 2019 dan penyusunan laporan akan dilakukan pada bulan desember.

Pada tahap pengadaan fasilitas tm PkM membantu dalam pengadaan fasilitas penunjang ekowisata Keranggan berupa perbaikan pintu gerbang ekowisata dan alat pemotong rumput Bentuk kegiatan Pengabdian Masyarakat pengembangan ekowisata Keranggan dan kriteria keberhasilan kegiatan diuraikan dalam tabel di bawah ini.
Kegiatan yang tidak dapat dilangsungkan adalah launching oleh pejabat Kota Tangerang, yang diakibatkan waktunya tidak sesuai dengan jadwal yang direncanakan pada desember 2018, dan akan direncanakan dilaksanakan tahun 2019.

Tabel 1. Hasil Kegiatan

\begin{tabular}{|c|c|c|c|}
\hline No & $\begin{array}{r}\text { Kriteria } \\
\text { Keberhasilan }\end{array}$ & Indikator & $\begin{array}{r}\text { Bentuk } \\
\text { Kegiatan }\end{array}$ \\
\hline 1 & $\begin{array}{l}\text { Penguasaan } \\
\text { pengetahuan } \\
\text { tentang } \\
\text { pengelolaan } \\
\text { ekowisata berbasis } \\
\text { masyarakat }\end{array}$ & $\begin{array}{l}\text { Peserta memahami } \\
\text { tentang: } \\
\text { a. Komponen } \\
\text { pendukung } \\
\text { pengelolaan } \\
\text { ekowisata berbasis } \\
\text { masyarakat } \\
\text { b. Dampak } \\
\text { pengelolaan } \\
\text { ekowisata berbasis } \\
\text { masyarakat }\end{array}$ & $\begin{array}{l}\text { Sosialisasi, } \\
\text { penyuluhan dan } \\
\text { pendampingan } \\
\text { tentang } \\
\text { pengelolaan } \\
\text { ekowisata berbasis } \\
\text { masyarakat: diskusi } \\
\text { dan praktek }\end{array}$ \\
\hline 2 & $\begin{array}{l}\text { Penguasaan } \\
\text { pengetahuan } \\
\text { tentang manfaat } \\
\text { kegiatan pariwisata }\end{array}$ & $\begin{array}{l}\text { Peserta memahami } \\
\text { tentang: } \\
\text { a. Konsep pariwisata } \\
\text { b. Manfaat } \\
\quad \text { pariwisata }\end{array}$ & $\begin{array}{l}\text { Sosialisasi dan } \\
\text { pendampingan } \\
\text { tentang manfaat } \\
\text { pariwisata: Diskusi } \\
\text { dan praktek }\end{array}$ \\
\hline 3 & $\begin{array}{l}\text { Peningkatan } \\
\text { pengetahuan } \\
\text { tentang } \\
\text { pengelolaan } \\
\text { ekowisata }\end{array}$ & $\begin{array}{l}\text { Peserta memahami } \\
\text { tentang: } \\
\text { a. Form yang } \\
\text { digunakan dalam } \\
\text { pengelolaan } \\
\text { ekowisata } \\
\text { b. Pembukuan } \\
\text { sederhana } \\
\text { c. Standar } \\
\text { pengelolaan } \\
\text { ekowisata }\end{array}$ & $\begin{array}{l}\text { Pelatihan dan } \\
\text { pendampingan } \\
\text { tentang } \\
\text { standar pengelolaan } \\
\text { ekowisata melalui } \\
\text { diskusi, praktek dan } \\
\text { kunjungan } \\
\text { lapangan }\end{array}$ \\
\hline 4 & $\begin{array}{l}\text { Penguasaan } \\
\text { pengetahuan } \\
\text { tentang pembuatan } \\
\text { paket dan brosur } \\
\text { wisata }\end{array}$ & $\begin{array}{l}\text { Peserta memahami } \\
\text { tentang: } \\
\text { a. Quotation untuk } \\
\text { pembuatan paket } \\
\text { wisata } \\
\text { b. Pola perjalanan } \\
\text { wisata }\end{array}$ & $\begin{array}{l}\text { Pelatihan dan } \\
\text { pendampingan } \\
\text { tentang pembuatan } \\
\text { paket dan brosur } \\
\text { wisata melalui } \\
\text { diskusi, praktik dan } \\
\text { kunjungan } \\
\text { lapangan }\end{array}$ \\
\hline 5 & $\begin{array}{l}\text { Peningkatan } \\
\text { kualitas layanan }\end{array}$ & $\begin{array}{l}\text { Peserta memahami } \\
\text { tentang: } \\
\text { a. Standar } \\
\text { penampilan } \\
\text { (grooming) } \\
\text { b. Cara } \\
\text { berkomunikasi } \\
\text { c. Standar layanan } \\
\text { d. Cara menangani } \\
\text { keluhan } \\
\text { (handling } \\
\text { complaints) }\end{array}$ & $\begin{array}{l}\text { Pelatihan dan } \\
\text { pendampingan } \\
\text { tentang kualitas } \\
\text { layanan melalui } \\
\text { diskusi dan praktik }\end{array}$ \\
\hline 6 & $\begin{array}{l}\text { Penguasaan materi } \\
\text { dan sarana promosi } \\
\text { dan } \\
\text { penyelenggaraan } \\
\text { kegiatan ekowisata }\end{array}$ & $\begin{array}{l}\text { Peserta memahami } \\
\text { tentang } \\
\text { a. Standar sarana } \\
\text { promosi paket } \\
\text { wisata } \\
\text { b. Standar } \\
\text { enyelenggaraan } \\
\text { event wisata }\end{array}$ & $\begin{array}{l}\text { Pelatihan dan } \\
\text { pendampingan } \\
\text { tentang pembuatan } \\
\text { media promosi } \\
\text { paket dan event } \\
\text { wisata melalui } \\
\text { diskusi dan praktik }\end{array}$ \\
\hline
\end{tabular}

Ekonomi, Sosial, dan Budaya 
Tabel 2 Evaluasi Penyelenggaraan Pelatihan

\begin{tabular}{|c|c|c|c|c|c|}
\hline $\mathrm{No}$ & Evaluasi & STS & TS & $\mathbf{S}$ & SS \\
\hline 1 & $\begin{array}{l}\text { Setelah mengikuti } \\
\text { pelatihan } \\
\text { pengetahuan } \\
\text { tentang saya } \\
\text { membuat paket wisata } \\
\text { yang sesuai dengan } \\
\text { kebutuhan analon } \\
\text { wisatawan meningkat } \\
\text { dari sebelumnya }\end{array}$ & & & & $100 \%$ \\
\hline 2 & $\begin{array}{lr}\text { Topik } & \text { perumusan } \\
\text { paket wisata yang } & \text { yalam } \\
\text { dibahas } & \text { dalam } \\
\text { pelatihan ini menjawab } & \text { permasalahan saya }\end{array}$ & & & $75 \%$ & $25 \%$ \\
\hline 3 & $\begin{array}{l}\text { Saya berpartisipasi } \\
\text { aktif dalam perumusan } \\
\text { paket wisata ini }\end{array}$ & & & & $100 \%$ \\
\hline 4 & $\begin{array}{l}\text { Fasilitas dan suasana } \\
\text { tempat pelatihan } \\
\text { mendukung belajar }\end{array}$ & & & & $100 \%$ \\
\hline 5 & $\begin{array}{l}\text { Fasilitator mendorong } \\
\text { peserta untuk } \\
\text { berpartisipasi }\end{array}$ & & & & $100 \%$ \\
\hline 6 & $\begin{array}{l}\text { Pelatihan ini } \\
\text { membantu saya } \\
\text { mengembangkan } \\
\text { usaha yang sedang } \\
\text { saya lakukan saat ini } \\
\text { dalam } \\
\text { mengembangkan } \\
\text { kegiatan wisata } \\
\text { menjadi lebih baik }\end{array}$ & & & $25 \%$ & $75 \%$ \\
\hline 7 & $\begin{array}{lr}\text { Pelatihan } & \text { ini } \\
\text { membantu peserta } \\
\text { untuk lebih percaya } \\
\text { diri dalam mengelola } \\
\text { usaha wisata saat ini }\end{array}$ & & & & $100 \%$ \\
\hline 8 & $\begin{array}{l}\text { Secara keseluruhan } \\
\text { saya mendapat manfaat } \\
\text { manfaat dari pelatihan } \\
\text { ini }\end{array}$ & & & & $100 \%$ \\
\hline
\end{tabular}

Berdasarkan evaluasi penyelenggaraan kegiatan pelatihan di atas menunjukkan sebagian besar peserta menunjukkan peningkatan pengetahuannya dalam membuat paket wisata sesuai dengan kebutuhan calon wisatawan. Di sisi yang lain pelatihan ini mendukung usaha yang sedang dilakukan dalam mengembangkan kegiatan ekowisata yang sedang dikembangkan di Keranggan.

Materi pelatihan yang berguna bagi peserta antara lain :

1. Pembuatan paket wisata

2. Menetukan rute sesuai dengan kebutuhan

peserta wisata
3. Membuat perhitungan biaya dan harga paket wisata

Saran perbaikan untuk kegiatan pelatihan mendatang, dibuat lebih menarik dan interaktif agar semua peserta selain mendapatkan pengetahuan juga praktek langsung.

\section{KESIMPULAN}

Program pengabdian masyarakat berhasil membentuk pengelola ekowisata berbasis masyarakat di kawasan Keranggan Kec Setu Kota Tangerang Selatan. Ekowisata Keranggan ini terbentuk setelah melakukan berbagai sosialisasi, penyuluhan dan pelatihan untuk masyarakat di sekitar kawasan Keranggan. Ekowisata Keranggan ini memiliki potensi sosial, ekonomi dan alam yang tinggi untuk meningkatkan kesejahteraan masyarakat di sekitar kawasan tersebut.

Untuk mendukung pengelola dalam pengembangkan kegiatan ekowisata di Keranggan dilakukan pelatihan mengenai pembuatan paket wisata, menentukan rute sesuai dengan kebutuhan peserta wisata, membuat perhitungan biaya dan harga paket wisata. Berdasarkan evaluasi penyelenggaraan kegiatan pelatihan di atas menunjukkan sebagian besar peserta menunjukkan peningkatan pengetahuannya dalam membuat paket wisata sesuai dengan kebutuhan calon wisatawan. Di sisi yang lain pelatihan ini mendukung usaha yang sedang dilakukan dalam mengembangkan kegiatan ekowisata yang sedang dikembangkan di Keranggan. Masukan untuk penyelenggaraan pelatihan mendatang agar dibuat lebih menarik dan interaktif agar semua peserta selain mendapatkan pengetahuan juga praktek langsung.

\section{UCAPAN TERIMAKASIH}

Terima kasih kepada staf dan pimpinan LPPM Universitas Pelita Harapan yang telah memberikan pendanaan kegiatan ini dengan nomor : PM-040/STPPH/VI/2018. 


\section{REFERENSI}

Departemen Kebudayaan dan Pariwisata dan WWF Indonesia. (2009). Prinsip dan Kriteria Ekowisata Berbasis Masyarakat. Diperoleh dari http://www.pfppwi.com/download/prinsip_dan_kriteria_ecoto urism_jan_2009.pdf.

Nugroho, Iwan. 2011. Ekowisata dan Pembangunan Berkelanjutan. Penerbit Pustaka Pelajar. Yogyakarta

Sekolah Tinggi Pariwisata Pelita Harapan (2012). Renstra Sekolah Tinggi Pariwisata Pelita Harapan 2012-2017. Tangerang: STPPH.

\section{Lampiran 1 : Dokumentasi Kegiatan}

A. Kegiatan Pelatihan

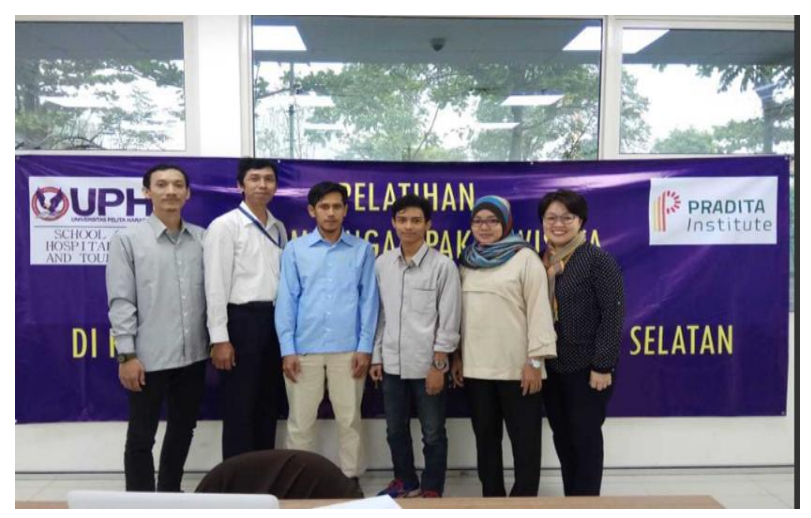

Gambar 1. Pelatihan Paket Wisata di

$$
\text { Keranggan }
$$

B. Media Promosi

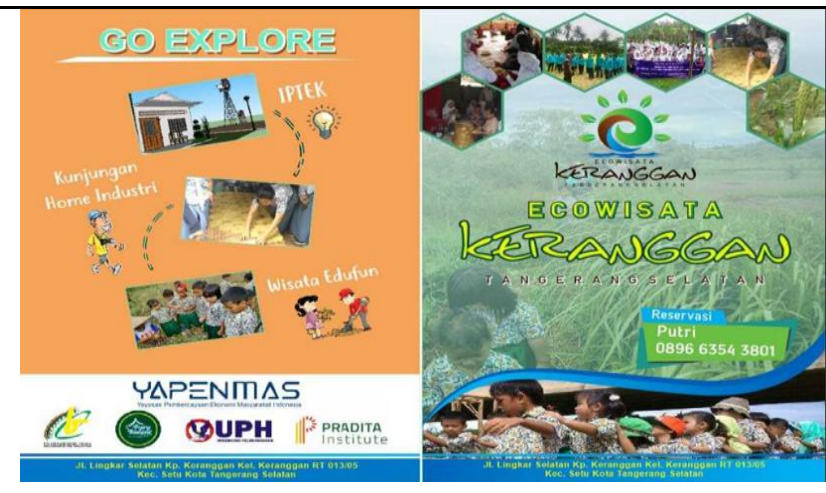

Gambar 2. Brosur Promosi Ekowisata

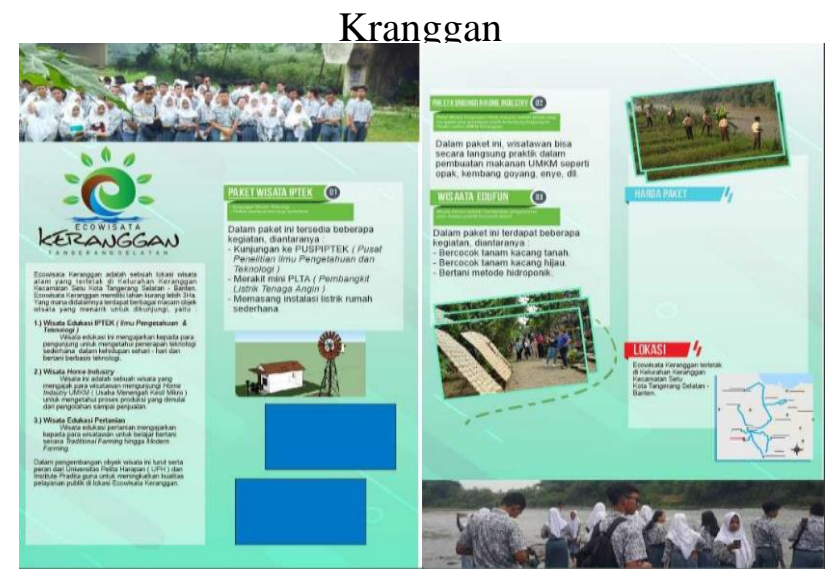

Gambar 3. Tampak Belakang Brosur Ekowisata Keranggan

C. Fasilitasi kegiatan

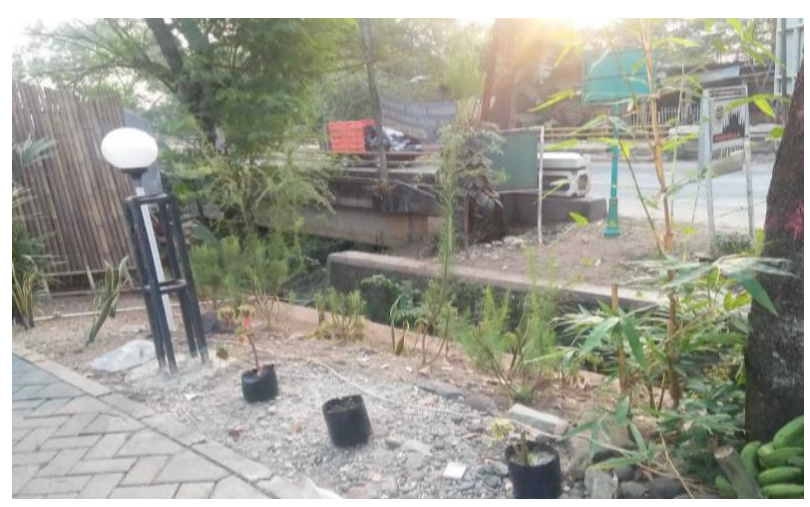

Gambar 3. Penampak Pitu Gerbang Eko Wisata Keranggan 